FACTA UNIVERSITATIS

Series: Visual Arts and Music Vol. 5, N 1, 2019, pp. 31 - 39

https://doi.org/10.22190/FUVAM1901031J

Original scientific paper

\title{
DIFFERENCES IN MUSIC PREFERENCES BETWEEN MUSICIANS AND NON-MUSICIANS
}

\author{
UDC 78.08:782/785
}

\section{Ana Jovančević ${ }^{1}$, Nebojša Milićević ${ }^{2}$, Danijela Zdravić Mihailović ${ }^{3}$}

${ }^{1}$ PhD Student, University of Niš, Faculty of Philosophy, Niš, Serbia

${ }^{2}$ University of Niš, Faculty of Philosophy, Niš, Serbia

${ }^{3}$ University of Niš, Faculty of Arts, Niš, Serbia

\begin{abstract}
The aim of this research was to check potential differences in music preferences between musicians and non-musicians. Music preferences were evinced by a short test on the topic (STOMP-R: Rentfrow \& Gosling 2003), of the four types of music: Reflexive and Complex, Intense and Rebellious, Upbeat and Conventional, Energetic and Rhythmic. A sample of 209 students from the University of Niš $(M=75 ; F=134), 112$ non-musicians and 97 of musicians, were asked to give their opinion. The results of the t-test showed that there are differences between musicians and non-musicians as far as the preferences for one type of music or another is concerned. Statistically significant differences were found for the Reflexive and Complex music ( $p=.000$ ), as well as for the Upbeat and Conventional music $(p=.001)$. All statistically significant differences were in favor of the musicians. These results show that musicians prefer Reflexive and Complex as well as Upbeat and Conventional music, while differences don't exist for the remaining two types of music. On the other hand, when it comes to differences in the preference for Upbeat and Conventional music, they can be attributed only to female subsample, so only female musicians differ from female nonmusicians when it comes to preference for this type of music $(p=.001)$, while male musicians don't differ from male non-musicians, on the preference for thins genre ( $p=.213)$.
\end{abstract}

Key words: upbeat and conventional music, reflexive and complex music, gender, musicians, non-musicians.

Received April 2019 / Accepted May 2019

Corresponding author: Ana Jovančevič

University of Niš, Faculty of Arts

E-mail: jutarnjakafa15@gmail.com 


\section{INTRODUCTION}

Traits specific for artists have been a topic of interest of thinkers, philosophers and, later on of psychologists since ancient times. Psychologists have shown that artists seem to be more introverted, independent and tender-minded in comparison with non-artists (Roy 1996). Likewise, other authors have shown that actors are often seen as extraverted and expressive, dancers seem to be somewhat unhappy, anxious, sometimes hypochondriac and low in self-esteem, and musicians somewhat introverted and not so adventurous. Singers are situated between actors and musicians on most of the attributes (MarchantHaycox \& Wilson 1992). As far as the aim of this paper is concerned, one category of artists is of our special interest. This category includes musicians.

For quite a few years research has undoubtedly proven that musicians differ from non-musicians. Those differences have been found in a number of aspects of those individuals, one of those aspects being even their physiology (e.g Park et al. 2014). Park and his associates show that musicians and non-musicians react differently on sadness and fear, both at behavioral and physiological levels. More precisely, sadness and fear, conveyed by music, are more arousing for musicians than for non-musicians (Park et al. 2014). Results of one other study have shown that musicians and non-musicians differ when it comes to the familiarity of music phrases, which is followed by differences in the Event-Related Potential (ERP; Besson \& Faita 1995). Most of the music phrases are more familiar to musicians, as it is expected. Researchers have also found differences in the grey matter of the brain, between musicians and non-musicians (Gaser \& Shlaug 2003). More precisely, musicians have developed more grey matter in an auditory and motor specialized part of the brain, which could be traced back to their beginnings of training those skills (Gaser \& Shlaug 2003). There are some quite interesting findings, regarding the way musicians and non-musicians process music. Namely, authors show that when exposed to music stimuli, musicians use primarily their left ear, while non-musicians use primarily their right ear (Johnson 1977). These results suggest that musicians use the left hemisphere of their brain to process music, while non-musicians use the right one (Johnson 1977). As we very well know, the left hemisphere is specialized in analyzing and thinking, while the right one is more of a "feeling" hemisphere. So these results suggest that non-musicians feel the music more than they think about it, while musicians think about music more than nonmusicians. All these research papers show that there are deep, even physiological differences between musicians and general population.

This paper is mainly interested in the reactions of both musicians and non-musicians to the different genres of music. There are studies that suggest that musicians and nonmusicians don't react differently on music, such as the study by Madsen and his associates (Madsen et al. 1993), which show that there are no differences between trained musicians and non-musicians regarding aesthetical responses to classical music (Madsen et al. 1993). Moreover, there is a study which suggests that musicians perceive tension in music with more accuracy when compared to non-musicians (Fredrickson 2000). Authors of one other study found that musicians recognize the changes in the pitch of pieces of music with more accuracy when compared to non-musicians (Tervaniemi et al. 2004). Although there are such studies, we are interested in examining if there are differences in a specific aspect of perception and reception of music. Namely, we are interested in the musical preferences of musicians and non-musicians. 
Music genres have been the topic of interest for many researchers, and many individual differences have been explored in the context of individually preferred genres. For example, Byo (1991) shows that a preference for a specific instrument among children depends upon the way that musical instrument has been presented to those children, by their teachers. More precisely, if the teacher uses more creative ways to present an instrument to a child, the chances that that child will be fond of precisely that instrument get higher. Lamont and Webb (2009) are interested in the way an individual chooses his or her favorite piece of music. They found out that a musical piece, which an individual has considered his or her favorite for a long period of time, is usually connected to an important, emotional event in that person's life. Peery and Peery (1986) find that exposure to music could increase the preference for that kind of music. Tarrant and his associates (Tarrant et al. 2001) show that adolescents estimate musical preference of their own group and other groups differently. They associate their own group with a preference for music connected with positive stereotypes, and other groups with preferences for music connected with more negative preferences. Burke and Gridley (1990) point out that musical preference between those with higher musical education and those with lower musical education are different. More precisely, these authors show that individuals with higher musical education like modern, more complex compositions, much more than individuals with lower musical education. Similar results have been found in some studies which examine preferences for world music. Namely, Fung (1996) finds that there are some aspects of music that are equally preferred by musicians and non-musicians, for example: fast tempo, loud, tonal-centered, having many different pitches, consonant, moderately embellished, smooth-sounding, and bright timbre. On the other hand, musicians prefer excerpts with complex texture, whereas non-musicians prefer the moderately complex texture. Some studies suggest that differences in preferences for music are quantitative. Namely, one research shows that musicians prefer music more than non-musicians, regardless of genre (Burke \& Gridley 1990; Hargreaves, Messerschmidt \& Rubert 1980; Smith \& Cuddy 1986). It has also been shown that musical training correlates with a higher liking for more serious music genres (Hargreaves, Comber \& Colley 1995). Geringer (1982, as cited by Hargreaves, Comber \& Colley 1995), also finds that college music students have shown marked preferences for classical composers, whereas their non-musician peers have shown preferences for popular composers.

There are also gender differences when it comes to music preferences. For example, a group of authors (Mc Cown et al. 1997) show that men prefer buss elevated music more than females do. Also, there are differences when it comes to the specific instrument boys and girls prefer. It has been found that girls show a significantly stronger preference for the piano, flute, and violin than boys, whereas boys express a stronger preference for the guitar, drums, and trumpet (O' Neill \& Boultona 1996).

From all we have stated above, it is clear that there are deeply rooted differences between musicians and non-musicians, even at a physiological level. It is also obvious that there is a lack of studies which examine specific differences between musicians and non-musicians when it comes to their preference for specific music genres. Taking into account all we have previously stated, the aim of this study is to examine differences between musicians and non-musicians when it comes to their preferences for types of music and music genres. We will also check differences between male and female respondents, because it has been shown that gender is also an important variable when it comes to musical preferences. 


\section{Methodology}

\subsection{The Sample}

The sample consisted of 209 respondents in total, students of the University of Niš. Out of 209 respondents, 112 were non-musicians $(\mathrm{M}=33 ; \mathrm{F}=79)$ and 97 were musicians $(\mathrm{M}=33 ; \mathrm{F}=79)$. The age range for the sample of non-musicians was from 19 to 23 years $(M=20.21)$, while the age range for the sample of musicians was from 20 to 26 $(\mathrm{M}=21.88)$.

\subsection{Instruments}

Musical preferences were explored using short preference test of music genres (STOMP-R: Rentfrow and Gosling 2003). Musical genres in this questionnaire were combined into four categories, that is, into four types of music: Reflexive and Complex music (for example: classical, jazz, new age, etc.), Intense and Rebellious music (for example: punk, rock, etc.), Upbeat and Conventional music (folk, gospel, pop, etc.), and Energetic and Rhythmic music (techno, funk, reggae, etc.).

\section{RESULTS AND DISCUSSION}

The data were analyzed using the t-test for independent samples, for each of two subsamples.

Table 1 Differences in music preferences between musicians and non-musicians

\begin{tabular}{lccc}
\hline Type of music & Group & $\mathrm{M}$ & $\mathrm{p}$ \\
\hline Reflexive and Complex & Non-musicians & 3.88 & \multirow{2}{*}{ Musicians } \\
& 5.11 & .000 \\
Intense and Rebellious & Non-musicians & 4.22 & \multirow{2}{*}{.441} \\
& Musicians & 4.07 & \\
Upbeat and Conventional & Non-musicians & 4.23 & .001 \\
& Musicians & 4.5 & \\
Energetic and Rhythmic & Non-musicians & 4.22 & \multirow{2}{*}{.918} \\
& Musicians & 4.24 & \\
\hline
\end{tabular}

In Table 1, we can see that there are differences between musicians and non-musicians when it comes to preferences for Reflexive and Complex as well as Upbeat and Conventional music, and that musicians prefer both types of music more than non-musicians. First, we see that musicians prefer Reflexive and Complex music more than non-musicians do. If we recall that this type of music includes genres such as: classical, jazz, new age, etc., these results can be understood. Namely, previous papers suggest that musicians show a higher level of preference for more serious genres than non-musicians do (Hargreaves, Comber \& Colley 1995), and genres such as classical, jazz, etc., definitely belong to more serious music genres.

Another difference between musicians and non-musicians is the difference in preference for Upbeat and Conventional music (folk, gospel, pop, etc.). When it comes to this type of music, it can't be said that this is serious music, but it can be questioned how complex it is. More precisely, this type of music can be viewed as complex music. So the 
differences in preferences between musicians and non-musicians which we saw in Table 1 can be explained by the complexity of the music, because, as shown in previous papers, musicians prefer more complex music (Burke and Gridley 1990).

Table 2 Differences in music preferences between male and female non-musicians

\begin{tabular}{lccc}
\hline Type of music & Group & $\mathrm{M}$ & $\mathrm{P}$ \\
\hline Reflexive and Complex & Male & 3.67 & \multirow{2}{*}{.899} \\
& Female & 3.61 & \\
Intense and Rebellious & Male & 3.98 & .754 \\
& Female & 3.78 & \\
Upbeat and Conventional & Male & 3.29 & .031 \\
& Female & 4.04 &. \\
Energetic and Rhythmic & Male & 4.03 & \multirow{2}{*}{.934} \\
& Female & 4.09 & \\
\hline
\end{tabular}

In Table 2, it can be seen that there are statistically significant differences between male and female non-musicians when it comes to preference for Upbeat and Conventional music. These differences are in accordance with previous research which suggests that men prefer more bass elevated music than females, only in this paper differences go in the opposite direction (McCown et al. 1997). Namely, Upbeat and Conventional music refers to genres such as folk, gospel, pop, etc. So this type of music refers to genres with less bass in them, and females prefer it more than males.

Table 3 Differences in music preferences between male and female musicians

\begin{tabular}{lccc}
\hline Type of music & Group & $\mathrm{M}$ & $\mathrm{P}$ \\
\hline Reflexive and Complex & Male & 5 & .308 \\
& Female & 5.18 & \\
Intense and Rebellious & Male & 4.11 & .807 \\
& Female & 4.05 & \\
Upbeat and Conventional & Male & 4.41 & \multirow{2}{*}{} \\
& Female & 4.56 & .443 \\
Energetic and Rhythmic & Male & 3.95 & \multirow{2}{*}{040} \\
& Female & 4.07 &. \\
\hline
\end{tabular}

In Table 3, it can be seen that there are statistically significant differences between male and female musicians in preferences for Energetic and Rhythmic music, and female respondents show a higher level of appreciation for this type of music. This type of music includes genres such as: techno, funk, reggae, etc. It can be seen that those differences are not in accordance with results from previous studies (McCown et al. 1997), which suggest that men prefer bass elevated music more than females. Results from this study could differ from those from previous research because, in this particular research, results were obtained from musically trained population while in the previous research this was not the case. Therefore, these results suggest that musically trained women prefer Energetic and Rhythmic music more than musically trained men. Genres which are in this 
category of music are still somewhat alternative genres, so maybe female musicians are prone to liking alternative genres more than male musicians.

Table 4 Differences in music preferences between male musicians and non-musicians

\begin{tabular}{cccc}
\hline Type of music & Group & $\mathrm{M}$ & $\mathrm{p}$ \\
\hline Reflexive and Complex & Non-musicians & 4.03 & \multirow{2}{*}{.003} \\
& Musicians & 5 & \\
Intense and Rebellious & Non-musicians & 4.41 & \multirow{2}{*}{.404} \\
& Musicians & 4.11 & \\
Upbeat and Conventional & Non-musicians & 4.04 & \multirow{2}{*}{.213} \\
& Musicians & 4.41 & \\
Energetic and Rhythmic & Non-musicians & 3.94 & \multirow{2}{*}{.978} \\
& Musicians & 3.95 & \\
\hline
\end{tabular}

In Table 4, it can be seen that there are statistically significant differences between male musicians and male non-musicians when it comes to preference for Reflexive and Complex music and that those estimations are higher in the group of musicians. These results suggest that musicians prefer Reflexive and Complex music more than non-musicians. The results are in accordance with the results from Table 1, regarding all musicians and all nonmusicians. These results could be explained in the same way as those from Table 1. Namely, on the one hand, previous papers suggest that musicians show a higher level of preference for more serious genres than non-musicians (Hargreaves, Comber \& Colley 1995), but also for more complex music (Burke and Gridley 1990), and, on the other hand, Reflexive and Complex music can be considered both serious and complex type of music. It can be seen that within male respondents there are no differences in the preference for the Upbeat and Conventional music, so we can assume that those differences in Table 1 can be accounted to the differences between female musicians and female non-musicians.

Table 5 Differences in music preferences between female musicians and non-musicians

\begin{tabular}{cccc}
\hline Type of music & Group & $\mathrm{M}$ & $\mathrm{p}$ \\
\hline Reflexive and Complex & Non-musicians & 3.89 & .000 \\
& Musicians & 5.18 & .00 \\
Intense and Rebellious & Non-musicians & 4.23 & \multirow{2}{*}{.425} \\
& Musicians & 4.05 &. \\
Upbeat and Conventional & Non-musicians & 4.06 & \multirow{2}{*}{.001} \\
& Musicians & 4.56 & \\
Energetic and Rhythmic & Non-musicians & 4.34 & \multirow{2}{*}{.427} \\
& Musicians & 4.47 & \\
\hline
\end{tabular}

In Table 5, it can be seen that there are statistically significant differences between female musicians and non-musicians on preferences for Reflexive and Complex, as well as Upbeat and Conventional music. Female musicians prefer both genres more than female non-musicians. These results are similar to those from the first table regarding differences between all the musicians, hence they could be explained in the same way. Previous papers suggest that musicians show a higher level of preference for more serious genres than nonmusicians do (Hargreaves, Comber \& Colley 1995), and genres such as classical, jazz, etc., 
definitely belong to more serious music genres. Another difference between musicians and non-musicians refers to the preference for Upbeat and Conventional music (folk, gospel, pop, etc.) and these differences probably could be explained by the music complexity. Previous papers have shown that musicians prefer more complex music (Burke and Gridley 1990). Explanation regarding preference for more complex music by musicians could also be used to account for differences between musicians and non-musicians regarding their preferences for Reflexive and Complex music. Of course, the complexity of music was not controlled in this study so explanations which take into account this variable should be taken with cushion and checked in further studies.

From the table above it can also be seen that, when it comes to female subsample, differences between musicians and non-musicians are also generated by the preference for Upbeat and Conventional music. Based on these results we can conclude that differences between musicians and non-musicians for the Reflexive and Complex music exist both for female and male subsamples, but when it comes to differences for the preference for Upbeat and Conventional music, they could be attributed to differences between female musicians and non-musicians.

\section{CONCLUSION}

The aim of this study is to examine the differences between musicians and nonmusicians when it comes to their preferences for types of music and music genres. We have checked differences between male and female respondents because it has been shown that gender is also an important variable when it comes to music preferences. We have seen, from the results, that there are differences between musicians and non-musicians when it comes to preferences for Reflexive and Complex as well as Upbeat and Conventional music. Musicians show higher levels of appreciation for all categories. Between male and female non-musicians, differences exist when it comes to preference for Upbeat and Conventional music. We have also noticed that statistically significant differences between male and female musicians exist regarding Energetic and Rhythmic music and that those differences are higher with female respondents. Differences also exist between male musicians and male non-musicians when it comes to preference for Reflexive and Complex music, and those differences are higher in the group of musicians. In the end, differences have also been found between female musicians and non-musicians on preferences for Reflexive and Complex and Upbeat as well as Conventional music. We can assume that musicians prefer more complex music and serious music and that this difference exists both for male and female musicians and can be seen in the differences in the preference for the Reflexive and Complex music. On the other hand, female musicians differ from female non-musicians as far as the preference for Upbeat and Conventional music is concerned. Since those differences have also been found in the general sample, on both male and female respondents, but not on all male subsamples, we can conclude that those differences in the general sample have been found because of the effect of the differences in the preference for this type of music on the female subsample.

We can also mention a possible relation between the four types of music we considered. Namely, if we compare Reflexive and Complex (classical, jazz, new age, etc.) and Upbeat and Conventional music (folk, gospel, pop, etc.) with Intense and Rebellious music (for example punk, rock, etc.) and with Energetic and Rhythmic music 
(techno, funk, reggae, etc.), it could be presumed that Reflexive and Complex and Upbeat and Conventional music are more complex types of music than Intense and Rebellious or than Energetic and Rhythmic music, judging by their musical genre. This is, of course, only a hypothesis and should, therefore, be tested by further research.

The theoretical contribution of this paper can be found in a deeper understanding of the way musicians differ from individuals without formal musical training and in the way they experience music. The practical contribution could be found in marketing. Namely, when it is clear what kind of music musicians and non-musicians prefer, this information could be used advertising products for musicians and for individuals without musical training, depending on what the target population is. These results also give us an important insight into the perception of music as one form of art and into the process of music reception. They also give us somewhat new knowledge regarding the role of individual differences appreciating music. Summing up these results, although small, they are an important step towards understanding the way people process, use and understand music, and especially understanding differences between musicians and nonmusicians in their relation to music.

Disadvantages of this research are, first of all, the nature of the sample. For further studies, we suggest the inclusion of an equal number of male and female respondents, for both musicians and non-musician subsamples. Also, one more disadvantage of our research is that musicians were students of music, so for further studies, we suggest the inclusion of musicians with experience and not only students of music. On the other hand, for further research with the student sample, we suggest proportional inclusion of students of the theoretical department of the Academy of music and those of instrumental departments, in order to check if there are any differences in musical preferences between the two.

In the end, we can conclude that differences in the preferences for music exist between musicians and non-musicians, besides all other differences found in previous studies.

Acknowledgment: The paper is a part of the research conducted within the project 183/1-16-9-01 University of Niš, Faculty of Philosophy, Department of Psychology: Applied psychology in the function of the quality of individual life in Community.

\section{REFERENCES}

Besson, M., \& Faïta, F., (1995), "An event-related potential (ERP) study of musical expectancy: Comparison of musicians with nonmusicians", Journal of Experimental Psychology: Human Perception and Performance, 21, Vol. 6: pp. 1278-1296.

Burke, J. M., \& Gridley, M. C., (1990), "Musical preferences as a function of stimulus complexity and listeners' sophistication", Perceptual and Motor Skills, 71: pp. 687-690.

Byo, J., (1991), "An Assessment of Musical Instrument Preferences of Third-Grade Children", Bulletin of council for research in music education, 110: pp. 21-32.

Fredrickson, W. E., (2000), "Perception of Tension in Music: Musicians versus Nonmusicians", Journal of Music Therapy, 37, Vol. 1: pp. 40-50.

Fung, C. V., (1996), "Musicians' and Nonmusicians' Preferences for World Musics: Relation to Musical Characteristics and Familiarity", Journal of Research in Music Education, 44, Vol. 1: pp. 60-83.

Gaser, C., \& Schlaug, G., (2003), "Gray Matter Differences between Musicians and Nonmusicians", Annals of the New York Academy of Sciences, 999, Vol. 1: pp. 514-517. 
Hargreaves, D. J., Comber, C., \& Colley, A., (1995), "Effects of Age, Gender, and Training on Musical Preferences of British Secondary School Students", Journal of Research in Music Education, 43, Vol. 3: pp. 242-250.

Johnson, P. R., (1977), "Dichotically-Stimulated Ear Differences in Musicians and Nonmusicians", Cortex, 13, Vol, 4: pp. 385-389.

Lamont, A., \& Webb, R., (2009), "Short and long-term musical preferences: what makes a favorite piece of music?", Psychology of Music, 38, Vol. 2: pp. 222-241.

Madsen, C. K., Byrnes, S. R., Capperella-Sheldon, D. A., \& Brittin, R. V., (1993), "Aesthetic Response to Music: Musicians versus Nonmusicians", Journal of Music Therapy, 30, Vol. 3: pp. 174-191.

Marchant-Haycox, S. E., \& Wilson, G. D., (1992), "Personality and stress in performing artists", Personality and Individual Differences, 13, Vol. 10: pp. 1061-1068.

McCown, W., Keiser, R., Mulhearn, S., \& Williamson, D., (1997), "The role of personality and gender in preference for exaggerated bass in music". Personality and Individual Differences, 23, Vol. 4: pp. 543-547.

O’Neill, S. A., \& Boultona, M. J., (1996), "Boys' and Girls' Preferences for Musical Instruments: A Function of Gender?" Psychology of Music, 24, Vol. 2: pp. 171-183.

Park, M., Gutyrchik, E., Bao, Y., Zaytseva, Y., Carl, P., Welker, L., \& Meindl, T., (2014), "Differences between musicians and non-musicians in neuro-affective processing of sadness and fear expressed in music". Neuroscience Letters, 566: pp. 120-124.

Peery, J. C., \& Peery, I. W., (1986), "Effects of Exposure to Classical Music on the Musical Preferences of Preschool Children Music", Journal of Research in Music Education, 34, Vol. 1: 24-33.

Rentfrow, P. J., \& Gosling, S. D., (2003), "The do re mi's of everyday life: The structure and personality correlates of music preferences", Journal of Personality and Social Psychology, 84: pp. 1236-1256.

Roy, D. D., (1996), "Personality Model of Fine Artists", Creativity Research Journal, 9, Vol. 4: pp. 391-394.

Smith, K. C., \& Cuddy, L. L., (1986), "The Pleasingness of Melodic Sequences: Contrasting Effects of Repetition and Rule-familiarity", Psychology of Music, 14, Vol. 1: pp. 17-32.

Tarrant, M., North, A. C., \& Hargreaves, D. J., (2001), "Social Categorization, Self-Esteem, and the Estimated Musical Preferences of Male Adolescents", The Journal of Social Psychology, 141, Vol. 5: pp. 565-581.

Tervaniemi, M., Just, V., Koelsch, S., Widmann, A., \& Schroger, E., (2004), "Pitch discrimination accuracy in musicians vs nonmusicians: an event-related potential and behavioral study", Experimental Brain Research, 161, Vol. 1: 1-10.

\section{RAZLIKE U PREFERENCIJAMA ZA RAZLIČITE TIPOVE MUZIKE IZMEĐU MUZIČARA I NEMUZIČARA}

Muzičke preferencije su operacionalizovane kratkim testom za merenje muzičkih preferencija (STOMP-R: Rentfrow \& Gosling, 2003) koji meri preferenciju četiri tipa muzike: Refleksivna $i$ Kompleksna, Intenzivna i Buntovna, Optimističnu i Konvencionalnu i Energetska i Ritmična. Uzorak je činilo 209 studenata univerziteta u nišu $(M=75 ; \check{Z}=134)$, od toga je bilo 112 nemuzičara i 97 muzičara. Rezultati $T$ testa su pokazali da postoje razlike između muzičara i nemuzičara u pogledu preferencija pojedinih tipova muzike. Statistički značajne razlike su nađene za Refleksivnu i Kompleksnu muziku ( $p=.000$ ), kao i u pogledu preferencije Optimistične i Konvencionalne muzike ( $p=.001)$. Sve statistički značajne razlike su u korist muzičara. Ovi rezultati pokazuju da muzičari u većoj meri preferiraju Refleksivnu i Kompleksnu, kao i Optimističnu i Konvencionalnu muziku, dok razlike ne postoje u pogledu preferencija preostala dva tipa muzike. Sa druge strane, kada su u pitanju preferencije za Optimističnu i Konvencionalnu muziku, one mogu biti pripisane razlikma u okviru ženskog poduzorka, tako da se samo žene muzičari razlikuju od žena nemuzičara kada su u pitanju preferencije za ovaj tip muzike $(p=.001)$, dok se muškarci muzičari ne razlikuju od muškaraca nemuzičara u pogledu preferenije ovog tipa muzike ( $p=.213)$.

Ključne reči: optimistična i konvencionalna muzika, refleksivna i kompleksna muzika, pol, muzičari, nemuzičari. 